\title{
Pengaruh Pemberian Ekstrak Daun Kluwih (Artocarpus camansi) Terhadap Penurunan Aktivitas SGPT Tikus Putih (Rattus norvegicus) Jantan Galur Wistar yang di Induksi Parasetamol Dosis Tinggi
}

\author{
Bara Pawana Satya Nagara \\ Dosen Fakultas Kedokteran, Universitas Hang Tuah, Jl. Arief Rachman Hakim No. 150 Sukolilo, Surabaya, 60111 \\ E-mail: barapsn@gmail.com
}

\begin{abstract}
Latar Belakang: Kebiasaan masyarakat Indonesia menggunakan obat-obatan yang mudah didapat seperti parasetamol, dimana parasetamol dijual secara bebas akan menyebabkan penyalahgunaannya menjadi lebih besar.Penyalahgunaan ini berakibat timbulnya efek samping seperti efek hepatotoksik yang menimbulkan kerusakan pada sel-sel hati. Pengendalian efek hepatotoksi didalam tubuh dapat dibantu dengan mengkonsumsi makanan yang mengandung antioksidan. .Ekstrak daun kluwih (Artocarpus camansi) memiliki kandungan antioksidan seperti flavanoid yang diyakini dapat menurunkan aktivitas SGPT dan mengurangi efek toksisitas hepar oleh parasetmol. Tujuan: Tujuan penelitian ini adalah untuk mengetahui pengaruh pemberian ekstrak daun kluwih (Artocarpus camansi) terhadap penurunan aktivitas SGPT tikus putih (Rattus norvegicus) jantan galur Wistar yang diinduksi parasetamol. Metode: Merupakan post-test only control group mengunakan hewan coba tikus putih jantan galur Wistar yang dikelompokkan menjadi 3 kelompok yaitu kelompok kontrol (-), kelompok kontrol (+), kelompok perlakuan yang mendapat terapi ekstrak daun kluwih (Artocarpus camansi) $500 \mathrm{mg} / \mathrm{Kg}$ BB. Hasil: Hasil penelitian menunjukkan pemberian ekstrak daun kluwih (Artocarpus camansi) dosis $\mathbf{5 0 0} \mathrm{mg} / \mathrm{kg} / \mathbf{B B} / \mathrm{hari}$ pada tikus tidak menurunkan secara bermakna aktivitas SGPT pada kelompok tikus yang diberi parasetamol dosis tinggi ( $\mathrm{p}=0,401 \alpha=0,05)$. Kesimpulan: Parasetamol dosis tinggi meningkatkan secara bermakna aktivitas SGPT tikus putih (Rattus norveicus) galur Wistar. Pemberian ekstrak daun kluwih (Artocarpus camansi) pada aktivitas SGPT tikus putih (Rattus norveicus) galur Wistar menurunkan secara tidak bermakna.
\end{abstract}

Keywords - : Artocarpus camansi; Parasetamol; SGPT.

\section{LATAR BELAKANG}

Parasetamol atau dengan nama lain asetaminofen merupakan obat analgesik dan juga antipretik yang digunakan sebagai pereda nyeri, sakit kepala, dan juga demam yang dianggap paling aman untuk terapi dengan dosis yang sesuai, sehingga obat ini dijual bebas tanpa resep. Karena penjualan nya yang bebas dan juga mudah didapatkan, penyalahgunaan paracetamol menjadi lebih besar (Mayasari, 2007). Penyalahgunaan paracetamol ini dapat berakibat timbulnya efek samping yang tidak diinginkan, diantaranya ialah efek hepatotoksik yang menimbulkan kerusakan pada sel-sel hati (Sheen et al., 2002). Hati merupakan organ yang sangat penting dalam tubuh manusia (Guyton \& Hall, 2006) (Jurnalis et al., 2015).

Parsetamol memiliki metabolit mayor yaitu sulfat dan glucoronida (Prescott, 2000). Kerusakan hati oleh parasetamol secara berlebihan terjadi karena terbentuknya metabolit reaktif toksik NAPQI ( $\mathrm{N}$-asetil-p-benzoquinon) dan radikal bebas melalui proses biotransformasi oleh enzim sitokrom P450 dengan bantuan isoenzim CYP2EI. Metabolit reaktif toksik dan radikal bebas dapat mengganggu integritas membran sel, berlanjut menjadi kerusakan hepar selanjutnya gagal ginjal (Kumala et al., 2016).

Pada dosis terapi, metabolit parasetamol yang sifat hepatotoksik dapat di detoksifikasi oleh glutation membentuk asam merkapturi yang bersifat non-hepatotoksik. kemudian di ekskresi kan melalui urine. Namun pada dosis yang berlebih produksi metabolit hepatotoksik melebihi kemampuan glutation untuk mendetoksifikasi, sehingga senyawa ini bereaksi dengan sel-sel hati lalu terjadi nekrosis sentrolobuler (Lusiana, 2002).

Adanya kerusakan pada hati dapat diketahui melalui peningkatan enzim-enzim transaminase dalam serum yang terdiri dari Aspartate Amino Transaminase / Glutamate Oxaloacetate Transaminase (AST/GOT) dan Alanine Amio Transferase / Glutamate Pyruvate Transaminase (ALT/GPT)(Sunarto, 1993).Radikal bebas dapat di netralisir oleh senyawa antioksidan (Ardhie, 2011) senyawa antioksidan ini dapat ditemukan pada berbagai macam tumbuhan salah satunya adalah pada daun kluwih (Artocarpus Camansi) .

Daun kluwih memiliki beberapa kandungan metabolit sekunder salah satunya adalah flavonoid, senyawa metabolit sekunder inilah yang berperan sebagai antioksidan alami (Agustikawati, Andayani and suhendra, 2016) Flavonoid berperan sebagai antioksidan dengan cara mendonasikan atom hidrogennya atau melalui kemampuannya mengkelat logam, berada dalam bentuk glukosida (mengandung rantai samping glukosa) atau dalam bentuk bebas yang disebut aglikon (Cuppett et al.,1954) senyawa flavonoid seperti quercetin, kaempferol, myricetin,apigenin, luteolin, vitexin dan isovitexin terdapat pada sereal, sayuran, buah danproduk olahannya dengan kandungan yang bervariasi serta sebagian besar memiliki sifat sebagai antioksidan. Hal ini telah memperkuat dugaan bahwa flavonoid memiliki efek biologis tertentu berkaitan dengan sifat antioksidatifnya (Madhavi, Deshpande and Salunkhe, 2017). 
Website : http://agritek.unmermadiun.ac.id/index.php/agritek

Berdasarkan teori tersebut peneliti tertarik untuk melakukan penelitian terhadap pengaruh ekstrak daun kluwih (Artocarpus Camansi) terhadap kadar SGPT pada tikus putih (Rattus Norvegicus) jantan galur wistar yang diinduksi parasetamol dosis tinggi.

\section{MATERI DAN METODE PENELITIAN}

Penelitian ini merupakan jenis penelitian eksperimental laboratoris secara in vivo pada hewan coba tikus putih (Rattus norvegicus). Penelitian ini menggunakan desain penelitian randomized post-test only control group design karena sampel darah tikus putih yang diambil untuk selanjutnya akan dilakukan perhitungan perlu jumlah yang cukup dan tidak memungkinkan bagi tikus putih untuk diambil sampel darah dua kali mengingat volume darah mencit yang terbatas. Variabel bebas dalam penelitian ini adalah pemberian terapi oksigen hiperbarik. Sedangkan variabel terikat penelitian ini adalah kadar glukosa dalam darah tikus.

Sampel yang digunakan adalah Tikus galur Wistar berkelamin jantan dengan usia 8-12 minggu (Layal, 2016). Tikus yang diujikan memiliki Kriteria inklusi yaitu merupakan Rattus norvegicus galur Wistar, dengan jenis kelamin jantan, memiliki berat sekitar 150 - 200 gram, dan tikus dalam kondisi fisik sehat, ditandai dengan mata jernih, bulu mengkilap, gerakan yang aktif, dan fesesnya baik atau tidak lembek. Sedangkan tikus akan di eksklusi apabila memiliki terdapat cacat secara anatomi dan mengalami sakit selama adaptasi dan perlakuan. Sampel akan dikeluarkan dari penelitian (drop out) apabila dalam masa penelitian hewan coba mati dan menderita penyakit lain, di samping yang disebabkan oleh perlakuan.

Berdasarkan rumus Federer(Federer, 1967) minimal jumlah sampel adalah 8 tikus pada tiap kelompoknya. Tikus akan dibagi dalam 3 kelompok sehingga total tikus yang dibutuhkan adalah 24 ekor dengan rincian pembagian kelompok yaitu:

1. $\mathrm{K}(-)$ : Kelompok kontrol negative

2. $\mathrm{K}(+)$ : Kelompok kontrol positif

3. $\mathrm{P} \quad$ : Kelompok perlakuan diberi ekstrak daun kluwih

Sebelum dilakukan perlakuan tikus akan di adaptasikan terlebih dahulu selama 14 hari. Percobaan dimulai setelah dilakukan adaptasi selama 14 hari dan percobaan berlangsung selama 10 hari. Tiap kelompok akan mendapatkan perlakuan sebagai berikut:

1. Kontrol negatif: Rattus norvegicus diberikan sonde air minum yang telah difilter dan makanan standar selama 8 hari

2. Kontrol positif: Rattus norvegicus diberikan sonde air minum yang telah difilter dan makanan standar selama 8 hari dan parasetamol dosis $1750 \mathrm{mg} / \mathrm{kgBB}$ dalam CMC-Na $1 \%$ pada hari ke-8, 2 jam setelah pemberian air minum terakhir.

3. Perlakuan: Rattus norvegicus diberikan makanan standar dan sonde ekstrak daun kluwih dengan dosis $500 \mathrm{mg} / 200 \mathrm{grBB}$ selama 8 hari. Ekstrak diberi secara oral per-sonde. Pada hari ke-8, 2 jam setelah pemberian ekstrak daun kluwih kelompok perlakuan diberi parasetamol dosis $1750 \mathrm{mg} / \mathrm{kgBB}$ (Hidayanti, 2011)

Pada hari ke-10 semua Rattus norvegicus dianastesi untuk diambil darah. Pengambilan sampel darah Rattus norvegicus dengan cara cardiac puncture. Pengambilan dengan cardiac puncture merupakan cara yang baik untuk memperoleh darah dalam jumlah besar, tetapi prosedur ini merupakan prosedur terakhir (Prastiana D., 2010) Darah yang diambil akan dilakukan Pengukuran aktivitas SGPT dalam darah dilakukan dengan metode Bergmeyer (1978).

Data yang diperoleh dalam penelitian ini diolah dengan perhitungan rerata (mean) dan standar deviasi variabel SGPT. Selanjutnya dilakukan uji normalitas variabel tersebut dalam setiap kelompok pada semua pengamatan dengan menggunakan uji Saphiro Wilks. Tingkat kemaknaan $\alpha$ yang dipakai adalah 5\% (Steel \& Torrie, 1991 ; Sudjana, 1984). Bila data berkontribusi normal dan homogen, dilakukan analysis of variance (Anova) yang dilanjutkan dengan Post-Hoc Least Significance Difference (LSD). Tingkat kemaknaan $\alpha$ yang dipakai adalah 5\% (Steel \& Torrie, 1991 ; Sudjana, 1984). Apabila data tidak terdistribusi normal atau tidak homogen, maka digunakan uji Kruskal-Wallis dengan derajat kemaknaan $5 \%$ yang dilanjutkan dengan uji Mann-Whitney.

\section{III.HASIL PENELITIAN}

\section{Deskriptif dan Analisa Data}

Tabel 1. Hasil pengamatan Sampel

\begin{tabular}{ccccccc}
\hline \multirow{2}{*}{$\begin{array}{c}\text { Kelompok } \\
\text { Perlakuan }\end{array}$} & \multicolumn{3}{c}{ Hasil Uji Gula darah } & Normalitas & Homogenitas & P-Value \\
\cline { 2 - 4 } (Transformasi) & Min & Maks & Rata-rata & & & 0,001 \\
K(-) & 63,00 & 109,00 & 78.450 & 0,167 & 0,001 & \\
K(+) & 128,00 & 205,00 & 205.275 & 0,124 & 0,616 & \\
K(P) & 78,00 & 128,00 & 145.388 & & \\
\hline
\end{tabular}

Berdasarkan Tabel 1 Rerata aktivitas SGPT kelompok hewan coba yang diberi CMC-Na 1\% adalah 78,450 mg/dl, kelompok hewan coba yang diberi parasetamol dosis tinggi $205.275 \mathrm{mg} / \mathrm{dl}$, dan kelompok hewan coba yang diberi parasetamol dosis tinggi dan ekstrak daun kluwih $145.388 \mathrm{mg} / \mathrm{dl}$.

Data terlebih dahulu dilakukan uji normalitas dengan menggunakan uji Saphiro-Wilk. Data dikatakan terdistribusi normal apabila nilai signifikansi lebih dari 0,05 ( $>$ >0,05). Hasil uji normalitas masing-masing kelompok yang meliputi aktivitas SGPT 
Website : http://agritek.unmermadiun.ac.id/index.php/agritek

kelompok hewan coba yang diberi CMC-Na $1 \% 0.167$ ( $\mathrm{p}>0.05)$, kelompok hewan coba yang diberi parasetamol dosis tinggi 0.124 ( $>>0.05$ ), dan kelompok hewan coba yang diberi parasetamol dosis tinggi dan ekstrak daun kluwih 0.616 ( $>0.05$ ). Hal ini memiliki arti data SGPT terdistribusi normal.

Selain uji normalitas, uji asumsi yang perlu dilakukan yaitu uji homogenitas. Uji homogenitas dilakukan dengan uji levene's test. Dari data diatas diketahui nilai signifikasi adalah $0.001(<0.05)$. Hal ini berarti data tidak homogen. Karena hasil distribusi data normal dan uji homogenitas data tidak homogen, maka uji statistik yang akan digunakan ialah non-parametrik dengan uji Kruskal Wallis.

Berdasarkan hasil Uji Kruskal Wallis untuk membandingkan apakah terdapat perbedaan bermakna antara kelompok hewan coba yang diberi CMC-Na 1\%, kelompok hewan coba yang diberi parasetamol dosis tinggi, dan kelompok hewan coba yang diberi parasetamol dosis tinggi dengan ekstrak daun kluwih (Artocarpus camansi) pada Tabel 1 diperoleh nilai signifikasi $=$ 0.001. Maka dapat diambil kesimpulan bahwa "terdapat perbedaan aktivitas SGPT antara ketiga kelompok". Untuk mengetahui kelompok mana yang mempunyai perbedaan bermakna, maka dilakukan analisis Post-Hoc menggunakan uji Mann-Whitney.

\section{Uji Post-Hoc}

\begin{tabular}{cccccc}
\hline $\begin{array}{c}\text { Uji Komparasi } \\
\text { perbandingan }\end{array}$ & $\begin{array}{c}\text { Rerata kadar } \\
\text { glukosa }\end{array}$ & VS & $\begin{array}{c}\text { Rerata kadar } \\
\text { glukosa }\end{array}$ & P-Value & Keterangan \\
\hline K(-) vs K(+) & 86,00 & VS & 158,11 & 0,003 & Signifikan \\
K(-) vs K(P) & 86,00 & VS & 97,00 & 0,001 & Signifikan \\
K(+) vs K(P) & 158,11 & VS & 97,00 & 0,401 & Tidak signifikan \\
\hline
\end{tabular}

Berdasarkan hasil uji perbandingan Mann-Whitney didapatkan hasil perbandingan dari masing-masing kelompok. Untuk perbandingan kelompok hewan coba yang diberi CMC-Na 1\% dengan kelompok hewan coba yang diberi parasetamol dosis tinggi adalah $p=0.003$. Perbandingan kelompok hewan coba yang diberi pakan standar dengan kelompok hewan coba yang diberi parasetamol dosis tinggi adalah $p=0,001$, sedangkan perbandingan antara kelompok hewan coba yang diberi parasetamol dosis tinggi dengan kelompok hewan coba yang diberi parasetamol dosis tinggi dan ekstrak daun kluwih adalah $\mathrm{p}=$ 0.401 .

\section{IV.DISKUSI}

Berdasarkan hasil analisis data, rerata aktivitas SGPT kelompok hewan coba yang hanya diberi parasetamol dosis tinggi $(205,275 \mathrm{U} / \mathrm{L})$ menunjukkan peningkatan yang bermakna $(\mathrm{p}=0,003)$ bila dibandingkan dengan kelompok hewan coba yang hanya diberi CMC-Na $1 \%(78,450 \mathrm{U} / \mathrm{L})$. Keadaan ini menunjukkan bahwa pemberian parasetamol dosis tinggi dapat meningkatkan secara bermakna aktivitas SGPT dibandingkan kelompok yang hanya diberi pakan standar. Kemudian berdasarkan hasil analisis data, rerata aktivitas SGPT kelompok hewan coba yang diberi parasetamol dosis tinggi dan ekstrak daun kluwih $(145,388 \mathrm{U} / \mathrm{L})$ menunjukkan penurunan yang tidak bermakna $(\mathrm{p}=0,401)$ dibandingkan dengan kelompok hewan coba yang diberi parasetamol dosis tinggi $(205,275 \mathrm{U} / \mathrm{L})$. Keadaan ini menunjukkan bahwa pemberian ekstrak daun kluwih tidak dapat menurunkan secara bermakna aktivitas SGPT dibandingkan kelompok yang diberi parasetamol dosis tinggi.

Terdapat 2 faktor utama yang menentukan kemungkinan timbulnya kerusakan hati akibat parasetamol, yaitu meningkatnya jumlah produksi NAPQI ( $N$-acetyl-p-benzoquinone-imineI) oleh sitokrom P450 dan menurunnya produksi gluthatione sebagai hepatoprotektor (Katzung, 2018). Bila terjadi dosis toksik parasetamol, glutation hepar total menurun hingga 90\%. Akibatnya metabolit parasetamol berikatan kovalen dengan sistein. Ikatan kovalen antara metabolit parasetamol dan protein menyebabkan sel kehilangan fungsi atau aktivitasnya , bahkan terjadi kematian dan lisis sel tersebut (James, 2003). Kerusakan sel hati disebabkan oleh metabolit toksik dari parasetamol yaitu NAPQI ( $N$-acetyl-p-benzoquinon-imine) yang terbentuk dalam jumlah berlebihan. Akibatnya jumlah dari glutation yang tersedia tidak cukup (Dart, 2004). Glutation membentuk asam merkapturi yang bersifat non toksik dan diekskresikan melalui urine, tetapi pada dosis berlebih produksi metabolit hepatotoksik meningkat melebihi kemampuan glutation untuk mendetoksifikasi, sehingga metabolit tersebut bereaksi dengan sel-sel hepar dan menimbulkan nekrosis lobulus sentral (Darsono, 2002).

Aktivitas ALT (SGPT) normal ditemukan sebagian besar di hati karena konsentrasi terbesarnya berada di hati. Enzim ini dilepaskan ke dalam aliran darah akibat dari adanya kerusakan pada hati. Oleh karena itu, enzim ini mempunyai tingkat spesifisitas yang sangat tinggi sebagai indikator status hati (Davis et al., 2014). Kadar SGOT dan SGPT tidak merefleksikan fungsi hati tetapi lebih mengarah ke deteksi adanya inflamasi atau kerusakan pada hati (Davis et al., 2014). Bila terjadi kerusakan hati maka SGPT akan meningkat.

Tanaman kluwih dapat dijadikan sebagai tanaman obat karena kandungan kimia aktif pada tanaman tersebut yang sebagian besar merupakan senyawa metabolit sekunder. Senyawa metabolit sekunder inilah yang berperan sebagai antioksidan alami (Agustikawati et al, 2016) Berdasarkan hasil analisa fitokimia diperoleh kandungan pada daun kluwih dengan posisi yg berbeda ialah alkaloid, steroid, terpenoid, flavonoid, saponin, fenolik dan tannin (Permata and Asben, 2014). Flavonoid berperan sebagai 
Website : http://agritek.unmermadiun.ac.id/index.php/agritek

antioksidan dengan adanya aktivitas free radical scavenging. Flavonoid dengan potensial tinggi (FIOH) akan mengikat radikal bebas $(\mathrm{R} \bullet)$ dimana flavonoid akan memberikan atom radical $(\mathrm{FIOH} \bullet)$ dan menjadi molekul yang lebih stabil $(\mathrm{RH})($ Denisov et al., 2005; Stavridis, 2008).

Flavonoid meningkatkan ekspresi enzim Glutation S-transferase (GST) sehingga mempercepat proses detoksifikasi NAPQI melalui konjugasi dengan GSH menjadi asam merkapturat bersifat hidrofilik sehingga mudah diekskresikan melalui urin. Flavonoid akan mereduksi radikal bebas, menghasilkan senyawa yang lebih stabil dan kurang reaktif (Katzung \& Trevor, 2015). Beberapa penelitian menggunakan Artocarpus altilis kultivar tak berbiji atau sukun dalam bentuk infusa dilakukan oleh Kristianti (2003), menyatakan infus daun sukun segar dengan konsentrasi $45 \%$, infusa daun sukun kering oleh sinar matahari dengan konsentrasi $18 \%$, maupun kering oleh angin dengan konsentrasi $18 \%$ dapat menurunkan kadar gula darah dan kadar SGPT tikus putih hiperglikemik.

\section{KESIMPULAN}

Pemberian ekstrak daun kluwih (Artocarpus camansi) terhadap penurunan aktivitas SGPT pada tikus putih (Rattus norvegicus) jantan galur Wistar yang diinduksi parasetamol dosis tinggi meningkatkan secara bermakna aktivitas SGPT tikus putih (Rattus norveicus) galur Wistar. Dan pemberian ekstrak daun kluwih (Artocarpus camansi) menurunkan secara tidak bermakna. aktivitas SGPT tikus putih (Rattus norveicus) galur Wistar.

\section{VI.DAFTAR PUSTAKA}

Agustikawati, N., Andayani, Y. and suhendra, dedy (2016) 'Jurnal penelitian pendidikan ipa', Penelitian-Pendidikan, 98(4), pp. 0-12.

Ardhie, A. M. (2011) Radikal Bebas dan Peran Antioksidan dalam Mencegah Penuaan, MEDICINUS : Scientific Journal of Pharmaceutical Development and Medical Application.

Dart, R. C. (2004) Medical toxicology. Philadelphia, PA: Lippincott, Williams \& Wilkins.

Davis, C.P., Shiel, W. C. (2014) Liver Blood Test. USA.

Denisov, I. et al. (2005) Structure and Chemistry of Cytochrome P450, Chemical reviews. doi: 10.1021/cr0307143.

Federer, W. T. (1967) Experimental Design: Theory and Application. Oxford \& IBH Publishing Company.

Guyton, A. C. and Hall, J. E. (2006) Textbook of Medical Physiology, Textbook of Medical Physiology. doi: 10.1136/pgmj.51.599.683-c.

i kumala, N., Masfufatun and D.R, emilia (2016) 'POTENSI EKSTRAK DAUN KELOR ( Moringa Oleifera ) SEBAGAI HEPATOPROTEKTOR PADA TIKUS PUTIH ( Rattus Novergicus ) POTENTIAL EXTRACT OF Moringa Oleifera AS HEPATOPROTECTIVE IN WHITE RATS ( Rattus novergicus ) INDUCED TOXIC DOSES OF', 5(dose C), pp. 58-66.

James, L. P., Mayeux, P. R. and Hinson, J. A. (2003) 'ACETAMINOPHEN-INDUCED HEPATOTOXICITY', Drug Metabolism and Disposition, 31(12), p. 1499 LP-1506.

Jurnalis, Y. D., Sayoeti, Y. and Moriska, M. (2015) 'Kelainan Hati akibat Penggunaan Antipiretik', jurnal Kesehatan Andalas, 4(3), pp. 978-987.

Katzung, B. G. and Trevor, A. (2015) Basic \& Clinical Pharmacology13th Edition, Basic and Clinical Pharmacology.

Layal, K. (2016) 'Peran Nrf2 Dalam Patogenesis Stres Oksidatif dan Inflamasi pada Penyakit Ginjal Kronik Pendahuluan', 7(1).

Lusiana (2002) 'Diagnosis dan Terapi Intoksikasi Salisilat dan Parasetamol', Jkm, 2(1), pp. 30-38.

Madhavi, D. L., Deshpande, S. S. and Salunkhe, D. K. (2017) 'Food antioxidants: technological , toxicological , and health perspectives / edited by', (November).

Mayasari, S. (2007) 'Pengaruh pemberian asetaminofen berbagai dosis terhadap kadar ureum dan kreatinin serum tikus wistar', Group, pp. 1-23.

Permata, A. D. and Asben, A. (2014) 'KARAKTERISTIK DAN SENYAWA BIOAKTIF EKSTRAK KERING DAUN KLUWIH DARI POSISI DAUN YANG BERBEDA Deivy Andhika Permata dan Alfi Asben'.

Prastiana D., S. (2010) PERBEDAAN EFEK PEMBERIAN LENDIR BEKICOT (Achatina fulica) DAN GEL BIOPLACENTON TM TERHADAP.

Prescott, L. F. (2000) 'Paracetamol, alcohol and the liver', British Journal of Clinical Pharmacology, pp. 291-301. doi: 10.1046/j.1365-2125.2000.00167.x.

Sheen, C. L. et al. (2002) 'QJM to the health-care system', Oxford University Press, 95(9), pp. 609-619.

Stavridis, J. C. (2008) Oxidation: the cornerstone of carcinogenesis : oxidation and tobacco smoke carcinogenesis. A relationship between cause and effect. Dordrecht; London: Springer.

Sunarto (1993) 'Modul Kesehatan dan Keselamatan Kerja (K3) dan Kesehatan Lingkungan', 14(4), pp. 1-37. 